\title{
Experimental research of intake air filtering fibers in motor vehicle engines
}

\begin{abstract}
Properties of filtering materials used as porous barriers in filter elements of motor vehicle air cleaners have been analyzed. Criteria of fiber and paper selection for the filter elements have been presented. A relation showing the filter life and a coefficient of dust absorption $\mathrm{km}$ of filtering materials have been presented. A methodology of research of the fiber filter element characteristics has been developed. Results of investigations of the characteristics of efficiency, filtering accuracy and drag of the filtering fiber operating at different filtering rates have been presented. The coefficients of dust absorption km of the filtering fiber have been determined. Changes in the granulometric properties of dust in the airflow downstream of the filtering fiber and paper have been presented.
\end{abstract}

Key words: combustion engines, air filtration, filter characteristics, filtering fiber

\section{Badania eksperymentalne włókniny do filtracji powietrza wlotowego silników spalinowych pojazdów mechanicznych}

\begin{abstract}
Przeanalizowano właściwości materiatów filtracyjnych stosowanych jako materiat na przegrody porowate w filtrach powietrza pojazdów mechanicznych. Przedstawiono kryteria doboru wtókniny i papieru filtracyjnego do filtru. Przedstawiono zależność określajaca czas pracy filtru powietrza oraz zdefiniowano wspótczynnik chłonności pylu km materiatu filtracyjnego. Opracowano metodykę badań charakterystyk wkładu filtracyjnego wykonanego z włókniny. Przeanalizowano wyniki badań charakterystyk skuteczności i dokładności filtracji oraz oporów przepływu włókniny filtracyjnej pracujacej przy różnych prędkościach filtracji. Określono współczynniki chłonności pyłu km włókniny filtracyjnej. Przedstawiono zmiany składu granulometrycznego pyłu w strumieniu powietrza za badana włóknina filtracyjna i papierem.

Słowa kluczowe: silniki spalinowe, filtracja powietrza, charakterystyki filtrów, włóknina filtracyjna
\end{abstract}

\section{Introduction}

Intake air cleaning in modern passenger vehicles and light duty trucks is realized through single stage air cleaners fitted with a porous barrier, most of the time in the form of a paper filter element $[1,3,5,7,13,14]$. There is also a solution, mostly applied in the Asian market (Japan, South Korea) utilizing filter elements made of filtering fiber.

The selection of filter elements in the air cleaner depends on the area of the filtering material resulting from the engine air demand $\mathrm{Q}_{\mathrm{Sil}}$ and the admissible filtration rate that amounts to (for filtration papers) $v_{\text {Fdop }}=0.03-0.12 \mathrm{~m} / \mathrm{s}[1,2,3,6,7$, 12] (the greater values are assumed for passenger vehicles.) In the case of filtration fibers, the calculated filtration rates are much higher, in the range from $v_{\text {Fdop }}=0.18-0.52 \mathrm{~m} / \mathrm{s}$ [5]. Mann+Hummel gives an admissible value of filtration for gradient structure fibers of $\mathrm{U}_{\text {Fdop }}=0.33 \mathrm{~m} / \mathrm{s}$ [3].

The filter life, until the obtainment of the assumed value $\Delta \mathrm{p}_{\text {fdop }}$, depends not only on the parameters of the filtering process in the porous barrier but also on its dust capacity. This property is characterized by coefficient of dust absorption $\mathrm{k}_{\mathrm{m}}$ whose value, determined with the use of standard test dust types of the grain size not exceeding $100 \mu \mathrm{m}$, reaches $220 \mathrm{~g} / \mathrm{m}^{2}$ in the case of cellulose based filtration materials $[1,3,6,11]$. For the fiber-based filtration materials, coefficient of dust absorption $\mathrm{k}_{\mathrm{m}}$ (given by few sources) reaches five times the value of those based on paper $\mathrm{k}_{\mathrm{m}}=900-1100$ $\mathrm{g} / \mathrm{m}^{2}$ [3]. Greater dust absorption of fiber structures allows a significant extension of maintenance intervals as compared to paper filter elements of similar filtration area or reducing

\section{Wstęp}

Do filtracji powietrza wlotowego silników we współczesnych samochodach osobowych oraz lekkich samochodach dostawczych stosuje się filtry jednostopniowe z przegroda porowatą, którą jest najczęściej wkład papierowy ukształtowany $\mathrm{w}$ formie panelu lub cylindra (pierścienia) $[1,3,5,7,13,14]$. Istnieją również rozwiązania, głównie w samochodach produkcji azjatyckiej (Japonia, Korea Płd.), w których przegrodę porowatą stanowi wkład wykonany $\mathrm{z}$ włókniny filtracyjnej.

Dobór wkładu filtracyjnego do filtru sprowadza się do określenia powierzchni materiału filtracyjnego, wynikającej z określonego zapotrzebowania powietrza przez silnik $\mathrm{Q}_{\mathrm{Sil}}$ oraz dopuszczalnej prędkości filtracji wynoszącej dla papierów filtracyjnych $v_{\text {Fdop }}=0,03-0,12 \mathrm{~m} / \mathrm{s}[1,2,3,6,7$, 12], przy czym wartości wyższe przyjmuje się dla samochodów osobowych. W odniesieniu do włóknin filtracyjnych obliczone prędkości filtracji przyjmują wartości znacznie większe w zakresie $v_{\text {Fdop }}=0,18-0,52 \mathrm{~m} / \mathrm{s}$ [5]. Firma Mann+Hummel jako dopuszczalną prędkość filtracji dla włóknin filtracyjnych o strukturze gradientowej podaje wartość $\mathrm{v}_{\text {Fdop }}=0,33 \mathrm{~m} / \mathrm{s}[3]$.

Czas pracy filtru do uzyskania założonej wartości $\Delta \mathrm{p}_{\text {fdop }}$ zależy nie tylko od parametrów procesu filtracji powietrza na przegrodzie porowatej, ale także od jej pojemności pyłowej. Właściwość tę charakteryzuje współczynnik chłonności pyłu $\mathrm{k}_{\mathrm{m}}$, którego wartość określona przy użyciu standardowych pyłów testowych o rozmiarach ziaren nieprzekraczających $100 \mu \mathrm{m}$ dochodzi do $220 \mathrm{~g} / \mathrm{m}^{2} \mathrm{w}$ przypadku materiałów filtracyjnych na bazie celulozy $[1,3,6,11]$. 
the size of the filter element and maintaining the original service interval.

Coefficient $\mathrm{k}_{\mathrm{m}}$ is defined as dust mass trapped on the surface of $1 \mathrm{~m}^{2}$ of the filtration paper for the assumed value of admissible drag $\Delta \mathrm{p}_{\text {fdop }}$ and determined by the quotient of total mass of dust $\mathrm{m}_{\mathrm{PF}}$ trapped and active area of filtration paper $\mathrm{F}_{\mathrm{c}}$ until value $\Delta \mathrm{p}_{\text {fdop }}$ is reached [6]:

$$
\mathrm{k}_{\mathrm{m}}=\frac{\mathrm{m}_{\mathrm{PF}}}{\mathrm{F}_{\mathrm{c}}}\left[\mathrm{g} / \mathrm{m}^{2}\right]
$$

However, in the available literature, both domestic and international, there is no exhaustive information related to coefficient of dust absorption $\mathrm{k}_{\mathrm{m}}$ of fibers used in cleaning of the intake air in motor vehicles. This coefficient is necessary to design a filtration system and determine its durability - vehicle mileage. It is, thus, recommended to perform experimental research in order to determine the value of coefficient of dust absorption $\mathrm{k}_{\mathrm{m}}$ of the filtering fiber for different operating conditions.

\section{Characteristics of filtration materials of the intake air cleaners in motor vehicles}

A currently dominating filtration material used in the production of intake air filter barriers for engines of motor vehicles in both single and multi stage air cleaners are filtering papers made in a variety of types by specialized companies such as: J.C. BINZER Papierfabrik, AHLSTROM, H\&V GMBH. These papers differ in their structural parameters and properties: gramature, thickness, air permeability, pore size and resistance to tear and burst.

Filtration paper is formed as a pleated band (Fig. 1a) that can be further shaped into proper filter elements. Most often the filter elements are formed into round or oval based cylinders (Fig. 1b) and panels (Fig. 1c). The most popular is the v-shaped pleat. Filtering fibers are also used for the manufacturing of the barrier filter elements in passenger vehicles, though they are not as popular as paper. As compared to filtration papers, they are characterized by double gramature, greater thickness and much lower rigidity [5]. a)

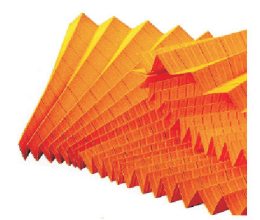

b)

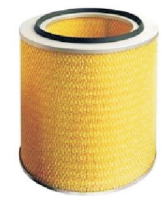

c)

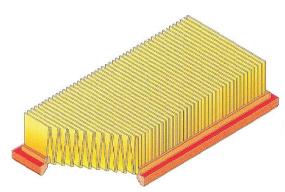

Fig. 1. Forms of paper filter elements: a) pleated band, b) cylindrical element, c) panel element [5]

Rys. 1. Ksztaltowanie wktadu filtracyjnego z papieru filtracyjnego: a) plisowana taśma, b) wkład cylindryczny, c) wktad panelowy [5]

Due to low rigidity of the pleats made on the filtration fibers the forming of a traditional filter element is a problem. A solution to this is fitting of the pleated fiber in a rigid plastic frame (Fig. 2b). Another solution that increases the rigidity of synthetic fibers is pleating of the fibers together with special
Dla materiałów filtracyjnych wykonanych z włóknin współczynnik chłonności pyłowej $\mathrm{k}_{\mathrm{m}}$, podawany $\mathrm{w}$ nielicznych źródłach, osiąga pięciokrotnie większą wartość 900-1100 g/m² [3]. Większa chłonność pyłowa włóknin pozwala na znaczne wydłużenie okresu eksploatacji wkładu w stosunku do wkładu papierowego o podobnej powierzchni filtracyjnej, bądź na zmniejszenie objętości wkładu filtracyjnego przy zachowaniu wymaganego okresu eksploatacji.

Współczynnik $\mathrm{k}_{\mathrm{m}}$ jest definiowany jako masa pyłu zatrzymana na powierzchni $1 \mathrm{~m}^{2}$ papieru filtracyjnego dla przyjętej wartości oporu dopuszczalnego $\Delta \mathrm{p}_{\text {fdop }}$ i określany ilorazem całkowitej masy pyłu $\mathrm{m}_{\mathrm{PF}}$ zatrzymanej i czynnej powierzchni papieru filtracyjnego $\mathrm{F}_{\mathrm{c}}$ do chwili osiągnięcia wartości $\Delta \mathrm{p}_{\text {fdop }}[6]$ - wzór (1).

Brak jest natomiast $\mathrm{w}$ dostępnej literaturze krajowej i zagranicznej wyczerpujących informacji na temat współczynnika chłonności pyłowej $\mathrm{k}_{\mathrm{m}}$ włóknin stosowanych do filtracji powietrza wlotowego silników pojazdów mechanicznych. Współczynnik ten jest niezbędny do zaprojektowania wkładu filtracyjnego i określenia czasu pracy filtru powietrza - przebiegu pojazdu. Dlatego uzasadnione jest przeprowadzenie badań eksperymentalnych celem określenia wartości współczynnika chłonności pyłowej $\mathrm{k}_{\mathrm{m}}$ włókniny filtracyjnej dla różnych warunków pracy.

\section{Charakterystyka materiałów filtracyjnych filtrów powietrza wlotowego silników pojazdów mechanicznych}

Dominującym obecnie materiałem filtracyjnym stosowanym do produkcji przegród filtracyjnych powietrza wlotowego silników spalinowych pojazdów mechanicznych w filtrach jedno- i wielostopniowych są papiery filtracyjne produkowane w wielu gatunkach, przez wyspecjalizowane firmy, na przykład: J.C. BINZER Papierfabrik, AHLSTROM, H\&V GMBH. Papiery te różnią się parametrami struktury i właściwościami: gramaturą, grubością, przepuszczalnością powietrza, wymiarami porów oraz wytrzymałością na rozerwanie i przepuklenie.

Papier filtracyjny kształtuje się w formie plisowanej taśmy (rys. 1a), z której następnie może być w różny sposób zmontowany wkład filtracyjny. Najczęściej wkłady filtracyjne ukształtowane są w cylindry o podstawie koła lub owalu (rys. 1b) oraz jako panelowe (rys. 1c). Najbardziej rozpowszechnione jest ukształtowanie plis w kształcie litery V. Do produkcji przegrodowych wkładów filtrów powietrza samochodów osobowych wykorzystywane są także, choć w mniejszym stopniu, włókniny filtracyjne. Charakteryzują się one, w stosunku do papierów filtracyjnych, dwukrotnie większą gramaturą, kilkakrotnie większą grubością oraz zdecydowanie mniejszą sztywnością [5].

Ze względu na małą sztywność plis wykonanych z włóknin filtracyjnych konstruowanie tradycyjnych wkładów filtracyjnych jest kłopotliwe. Rozwiązaniem tego problemu jest montowanie plisowanej włókniny w sztywnej ramce wykonanej z tworzywa sztucznego (rys. 2b). Innym rozwiązaniem zwiększającym sztywność włóknin syntetycznych jest plisowanie włóknin wraz ze specjalnymi siatkami z two- 
plastic meshes that protect the structure against damage during operation. Panel filter elements are also manufactured in a wet press stamping process (Fig. 2c). a)

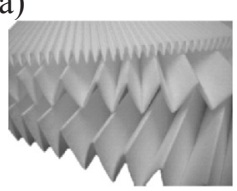

b)

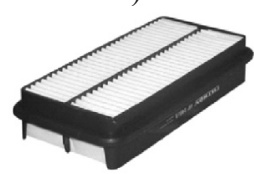

c)

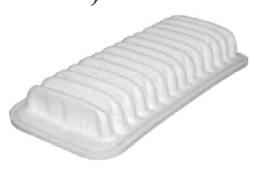

Fig. 2. The shapes of the fiber filter elements: a) pleated band, b) elements made from pleated fiber in a rigid frame, c) stamped panel element

Rys. 2. Kształtowanie wkładu filtracyjnego z włókniny filtracyjnej: a) plisowana taśma, b) wkład wykonany z plisowanej włókniny w sztywnej ramce, c) wktad panelowy $w$ formie wypraski

The properties of the filter elements are characterized by the following parameters:

- filtration efficiency - the quotient of dust mass $m_{p}$ trapped by the filter and mass of dust fed to the filter in time $m_{d}-$ weighted method:

$$
\varphi_{\mathrm{f}}=\frac{\mathrm{m}_{\mathrm{p}}}{\mathrm{m}_{\mathrm{d}}}
$$

- drag- difference of the pressures $p_{1}$ downstream and $p_{2}$ upstream of the filter:

$$
\Delta \mathrm{p}_{\mathrm{f}}=\mathrm{p}_{1}-\mathrm{p}_{2}
$$

- filtering accuracy - maximum $\mathrm{d}_{\mathrm{zmax}}$ size of the dust grain in the air downstream of the filter,

- absorption - mass of dust $\Delta \mathrm{m}$ trapped until the filter reaches a given drag (equal to $200 \%$ of the value of the drag of a clean filter at nominal airflow).

The life of a filter, limited by the admissible drag $\Delta \mathrm{p}_{\text {fdop}}$, is influenced not only by the absorption of the filtering barrier but also by the granulometric composition of dust that hits this barrier with air [6]. Manufacturers of filtration materials only provide data describing their structure and fail to give the filtration properties of the respective materials (papers and fibers). The relation between the material structure and its filtration characteristics are determined experimentally using standard tests. Life $\tau$ of a single stage air cleaner can be determined through an empirical dependence $[1,6]$ :

$$
\tau=\frac{\mathrm{F}_{\mathrm{c}} \cdot \mathrm{k}_{\mathrm{m}} \cdot \mathrm{k}_{\mathrm{c}}}{\mathrm{Q}_{\max } \cdot \mathrm{s} \cdot \varphi_{\mathrm{P}}}[\mathrm{h}]
$$

where: $\mathrm{F}_{\mathrm{c}}$ - area of the filtration material $\left[\mathrm{m}^{2}\right], \mathrm{k}_{\mathrm{m}}-$ material absorption coefficient for adopted $\Delta \mathrm{p}_{\text {fdop }}\left[\mathrm{g} / \mathrm{m}^{2}\right], \mathrm{k}_{\mathrm{c}}-$ coefficient allowing for the difference between the parameters of the test and actual contaminants, $Q_{\max }$ - nominal engine air demand $\left[\mathrm{m}^{3} / \mathrm{h}\right], \mathrm{s}-$ concentration of dust in the intake air $\left[\mathrm{g} / \mathrm{m}^{3}\right], \varphi_{\mathrm{P}}$ - efficiency of the filter element.

The problem in the correctness of the application of the above relation is the necessity to acquire a great deal of experimental data characterizing an individual filtering paper: rzyw sztucznych i tym samym uzyskuje się zabezpieczenie przed uszkodzeniami podczas eksploatacji. Produkowane są również panelowe wkłady filtracyjne wykonane z włóknin filtracyjnych w postaci wyprasek formowanych na mokro (rys. 2c).

Właściwości filtru powietrza są charakteryzowane przez następujące parametry:

- skuteczność filtracji - iloraz masy pyłu m $\mathrm{m}_{\mathrm{p}}$ zatrzymanego przez filtr i masy pyłu md dostarczonego do filtru w jednostce czasu - metoda wagowa - wzór (2),

- opór przepływu - różnica ciśnień całkowitych $\mathrm{p}_{1}$ przed i $\mathrm{p}_{2}$ za filtrem - wzór (3),

- dokładność filtracji - maksymalny $\mathrm{d}_{\mathrm{zmax}}$ rozmiar ziarna pyłu w powietrzu za filtrem,

- chłonność - masa pyłu $\Delta$ m zatrzymanego do chwili osiągnięcia przez filtr określonej wartości oporu przepływu (równego 200 \% wartości oporów przepływu dla czystego filtru przy nominalnym strumieniu powietrza).

$\mathrm{Na}$ czas pracy filtru, limitowanego osiągnięciem dopuszczalnego oporu przepływu $\Delta \mathrm{p}_{\text {fdop}}$, wpływa nie tylko chłonność przegrody filtracyjnej, ale także skład granulometryczny pyłu, jaki na nią trafia wraz z powietrzem [6]. Producenci materiałów filtracyjnych podają jedynie dane opisujące ich strukturę, brakuje natomiast informacji dotyczących właściwości filtracyjnych produkowanych materiałów (papierów i włóknin filtracyjnych). Relacje pomiędzy strukturą materiału a jego charakterystykami filtracyjnymi są ustalane eksperymentalnie z wykorzystaniem standardowych testów badawczych. Czas pracy $\tau$ jednostopniowego filtru powietrza można określić za pomocą empirycznej zależności (4) [1, 6]: gdzie: $\mathrm{F}_{\mathrm{c}}$ - powierzchnia materiału filtracyjnego $\left[\mathrm{m}^{2}\right], \mathrm{k}_{\mathrm{m}}$ - współczynnik chłonności materiału filtracyjnego dla przyjętego $\Delta \mathrm{p}_{\text {fdop }}\left[\mathrm{g} / \mathrm{m}^{2}\right], \mathrm{k}_{\mathrm{c}}$ - współczynnik uwzględniający różnicę między parametrami zanieczyszczeń testowych a rzeczywistych, $\mathrm{Q}_{\max }$ - nominalne zapotrzebowanie powietrza przez silnik $\left[\mathrm{m}^{3} / \mathrm{h}\right], \mathrm{s}-$ stężenie zapylenia powietrza zasysanego przez silnik $\left[\mathrm{g} / \mathrm{m}^{3}\right], \varphi_{\mathrm{P}}-$ skuteczność wkładu filtracyjnego.

Problem poprawności stosowania powyższej zależności stanowi konieczność posiadania jednak wielu danych doświadczalnych, które charakteryzują konkretny papier filtracyjny: współczynnik chłonności $\mathrm{k}_{\mathrm{m}}$, skuteczność filtracji $\varphi_{\mathrm{p}}$, a także współczynnik $\mathrm{k}_{\mathrm{c}}$ w określonych warunkach pracy, z których najważniejsze to: stężenie pyłu, jego skład chemiczny i granulometryczny, prędkość przepływu powietrza, rodzaj pyłu. Współczynnik k $\mathrm{c}_{\mathrm{c}}$ uwzględnia głównie wpływ sadzy na trwałość wkładu papierowego, a określany jest stosunkiem czasu pracy filtru w warunkach rzeczywistych do czasu pracy filtru przy zapyleniu pyłem testowym [1]. Znaczenie tego współczynnika, który przyjmuje wartości $\mathrm{k}_{\mathrm{c}}<1$ (im większa zawartość sadzy, tym wartość współczynnika k mniejsza), jest duże w przypadku filtrów powietrza z wkładem papierowym pojazdów eksploatowanych w warunkach miejskich i dróg klasycznych, gdzie sadza jest dominującym składnikiem zanieczyszczeń powietrza wlotowego do silnika. Dla silników pojazdów eksploatowanych w warunkach terenowych podstawowym składnikiem zanieczyszczeń 
coefficient of absorption $\mathrm{k}_{\mathrm{m}}$, filtration efficiency $\varphi_{\mathrm{p}}$, as well as coefficient $\mathrm{k}_{\mathrm{c}}$ under certain operating conditions, the most important of which are: dust concentration, its chemical and granulometric composition, airflow rate or type of dust. Coefficient $\mathrm{k}_{\mathrm{c}}$ mainly takes into account the influence of soot on the life of the paper filter element and is determined by the ratio of the operating time of a filter under actual conditions of operation to the time of operation of this filter on a test dust [1]. This coefficient, assuming value $\mathrm{k}_{\mathrm{c}}<1$ (the greater the amount of soot, the lower the value of coefficient $k_{c}$ ) is rather significant in the case of air cleaners fitted with a paper filter element in vehicles operated in urban conditions and traditional roads, where soot is the dominating component of the intake air. In the case of vehicle engines operated in off-road conditions the fundamental component is mineral dust; hence coefficient $\mathrm{k}_{\mathrm{c}}$ can be omitted when determining the life of a two-stage filter (under laboratory conditions using test dust), because test dust is similar to mineral dust in both chemical and granulometric composition.

Dust absorption coefficient $\mathrm{k}_{\mathrm{m}}$ for typical cellulose based filtration materials and standard types of dust of grain size not exceeding $100 \mu \mathrm{m}$ (dust of this grain size gets directly onto the filter element of a single stage air cleaner) is defined and assumes (until it reaches the predefined drag $\Delta \mathrm{p}_{\text {fdop }}$ ) maximum values in the range $\mathrm{k}_{\mathrm{m}}=190-220 \mathrm{~g} / \mathrm{m}^{2}[3,6]$. However, there are no data regarding the dust absorption of the filtration fibers, the knowledge of which is necessary for a proper selection of the filtering surface and determining the filter life.

That is why for the purpose of design of the filter element the filtration material characteristics are needed, particularly the coefficient of absorption (appropriate for the conditions of operation of the air cleaner.) The obtainment of such characteristics using currently applied methods and test stands for the actual dust concentrations and air demand is possible through experimental research of complete air cleaners. The performance of such research, particularly for cleaners applied in engines of high air demand is costly and time consuming.

This objective can be completed by a simple and cost efficient method, consisting in testing a special filter element (hereinafter referred to 'test filter element') of properly selected area of the filtration material with a proper filtration rate. Maintaining such operating conditions during the tests as those in the actual air cleaner, the obtained characteristics of the test filter element (a fragment of the filter element) can be treated as characteristics of the filter element of the actual size. The assumption is possible owing to the even distribution of dust on the entire surface of the filtration paper adopted in the definition of coefficient $\mathrm{k}_{\mathrm{m}}$.

The determination of the characteristics of the filtration material with the above unconventional method is possible in experimental research using appropriate methodology.

\section{Aim and scope of research}

The aim of the research was to determine coefficient of dust absorption $\mathrm{k}_{\mathrm{m}}$ of a filtration fiber for three different filtration rates: $v_{F}=0.08 \mathrm{~m} / \mathrm{s}, v_{F}=0.17 \mathrm{~m} / \mathrm{s}$ and $v_{F}=0.27 \mathrm{~m} / \mathrm{s}$. jest pył mineralny, a więc uwzględnianie współczynnika $\mathrm{k}_{\mathrm{c}}$ przy określeniu (w warunkach laboratoryjnych z użyciem pyłu testowego) czasu pracy filtru dwustopniowego można pominąć, gdyż pył testowy zbliżony jest do pyłu mineralnego zarówno składem chemicznym, jak i granulometrycznym.

Zachowując podczas badań takie warunki pracy badawczego wkładu filtracyjnego, jakie występują podczas pracy kompletnego filtru powietrza, można uzyskane charakterystyki badawczego wkładu filtracyjnego (wycinka wkładu filtracyjnego) potraktować jako charakterystyki. Współczynnik chłonności pyłu $\mathrm{k}_{\mathrm{m}}$ dla typowych materiałów filtracyjnych na bazie celulozy i standardowych pyłów, których rozmiar ziaren nie przekracza najczęściej $100 \mu \mathrm{m}$ (pył o takich rozmiarach ziaren trafia bezpośrednio na wkład filtracyjny filtru jednostopniowego) jest określony i przyjmuje, do chwili osiągnięcia założonego oporu dopuszczalnego $\Delta \mathrm{p}_{\text {fdop }}$, maksymalne wartości w zakresie $\mathrm{k}_{\mathrm{m}}=190-220 \mathrm{~g} / \mathrm{m}^{2}$ $[3,6]$. Brak jest natomiast danych dotyczących chłonności pyłowej włóknin filtracyjnych, których znajomość jest niezbędna do właściwego doboru powierzchni filtracyjnej i określenia czasu pracy filtru. Dlatego na potrzeby projektowania wkładu filtracyjnego filtru należy dysponować charakterystykami materiału filtracyjnego, a w szczególności współczynnikiem chłonności, odpowiednimi dla warunków pracy filtru powietrza. Uzyskanie takich charakterystyk z wykorzystaniem stosowanych obecnie metod i stanowisk badawczych dla rzeczywistych wartości stężenia zapylenia i zapotrzebowania powietrza przez silnik jest możliwe w trakcie badań eksperymentalnych kompletnych filtrów powietrza. Przeprowadzenie takich badań, zwłaszcza w odniesieniu do filtrów mających zastosowanie do silników o dużym zapotrzebowaniu powietrza, jest pracochłonne i kosztowne. Cel ten można osiągnąć metodą nieskomplikowaną i mniej kosztowną, polegającą na badaniu specjalnego wkładu filtracyjnego (nazywanego dalej „wkładem badawczym") o odpowiednio dobranej z kryterium prędkości filtracji powierzchni materiału filtracyjnego wkładu filtracyjnego w rzeczywistej wielkości. Założenie takie jest możliwe ze względu na przyjęty w definicji współczynnika $\mathrm{k}_{\mathrm{m}}$ równomierny rozkład pyłu na całej powierzchni czynnej papieru filtracyjnego wkładu.

Wyznaczenie w powyższy, niekonwencjonalny sposób charakterystyk materiału filtracyjnego jest możliwe podczas badań eksperymentalnych z wykorzystaniem odpowiedniej metodyki.

\section{Cel i zakres badań}

Celem badań było określenie współczynnika chłonności pyłowej $\mathrm{k}_{\mathrm{m}}$ włókniny filtracyjnej dla trzech różnych prędkości filtracji: $v_{F}=0,08 \mathrm{~m} / \mathrm{s}, v_{\mathrm{F}}=0,17 \mathrm{~m} / \mathrm{s}, v_{\mathrm{F}}=0,27 \mathrm{~m} / \mathrm{s}$.

Zakres badań obejmował określenie, z wykorzystaniem pyłu o standardowym składzie granulometrycznym, charakterystyk: skuteczności, dokładności filtracji i oporów przepływu wkładu filtracyjnego, w funkcji współczynnika chłonności pyłowej $\mathrm{k}_{\mathrm{m}}$, w postaci:

- skuteczność filtracji $\varphi_{\mathrm{w}}=\mathrm{f}\left(\mathrm{k}_{\mathrm{m}}\right)$,

- dokładności filtracji $\mathrm{d}_{\mathrm{zmax}}=\mathrm{f}\left(\mathrm{k}_{\mathrm{m}}\right)$,

- oporów przepływu $\Delta \mathrm{p}_{\mathrm{w}}=\mathrm{f}\left(\mathrm{k}_{\mathrm{m}}\right)$. 
The scope of the research covered the determination of the characteristics (using dust of standard granulometric composition): efficiency, filtration accuracy and filter element drag as a function of coefficient of dust absorption $\mathrm{k}_{\mathrm{m}}$, in the form:

- Filtration efficiency $\varphi_{\mathrm{w}}=\mathrm{f}\left(\mathrm{k}_{\mathrm{m}}\right)$,

- Filtration accuracy $\mathrm{d}_{\mathrm{z} \max }=\mathrm{f}\left(\mathrm{k}_{\mathrm{m}}\right)$,

- Drag $\Delta \mathrm{p}_{\mathrm{w}}=\mathrm{f}\left(\mathrm{k}_{\mathrm{m}}\right)$.

The object of the research was the only available filtration fiber AC-301 by Korea Filtration Technologies Co. (Tab. 1) shaped in a cylindrical filtration form.

The filtration fiber tests were performed for three filtration rates: filtration rates typical of filtration papers $v_{\mathrm{F} 1}=$ $=0.08 \mathrm{~m} / \mathrm{s}$, the rate close to that specified by Mann + Hummel as the maximum for filtration fibers $v_{\mathrm{F} 3}=0.27 \mathrm{~m} / \mathrm{s}$ and the intermediate rate of $\mathrm{v}_{\mathrm{F} 2}=0.17 \mathrm{~m} / \mathrm{s}$.

The tests were continued until the filter element reached the assumed admissible drag of at least $\Delta \mathrm{p}_{\text {fdop }}=5 \mathrm{kPa}$ and then, from relation 1 , coefficient of filtration fiber dust absorption $\mathrm{k}_{\mathrm{m}}$ was calculated.

\section{Methodology and research conditions of the filtration fiber}

In order to determine dust absorption coefficient $\mathrm{k}_{\mathrm{m}}$ we must know mass of the dust mWF trapped on the surface of the filtration fiber until the assumed drag $\Delta \mathrm{p}_{\text {fdop }}$ is reached

The tests were conducted on a test stand (Fig. 3) whose main elements are the cylindrical filter element made from the tests filtration fiber placed in a metal casing, the dust dispenser, the measurement duct, the rotameter and the absolute filter. The test stand was equipped with a particle counter (Pamas-2132 with a sensor HCB-LD-2A-2000-1) analyzing the granulometry of the particles in the airflow using laser dispersion (wavelength $680 \mathrm{~nm}$ ). The counter records the number and the size of the dust grains in the airflow in the range $0.7-100 \mu \mathrm{m}$ in $\mathrm{i}=32$ measurement intervals limited by the diameters $\left(\mathrm{d}_{\text {zimin }}-\mathrm{d}_{\text {zimax }}\right)$. The widths of the measurement intervals can be programmed freely. The device sensor is adapted to work at a maximum concentration of the particles in the air up to $1000 \mathrm{pieces} / \mathrm{ml}$, which corresponds to a mass dust flow of $\mathrm{s} \sim 0.25 \mathrm{~g} / \mathrm{m}^{3}$. The recording of the grains in the intake is realized in a measurement cycle during which several counts of the dust grains can be programmed. The results of the measurements are given in the form of tables (the number of tables corresponds to the number of programmed counts) containing the number of $\mathrm{N}_{i}$ grains of dust within the measurement intervals of diameters $\left(\mathrm{d}_{\mathrm{zimin}}-\mathrm{d}_{\text {zimax }}\right)$. In an appropriate distance downstream of the filter element a tip of a probe is located centrally in the axis of the duct aiming in the direction of the airflow $\mathrm{Q}$.

The measurement duct 3 has the absolute filter at the end securing the dust (slipped by the filter) from getting into the rotameter.

The proposed methodology enables the determination of coefficient $\mathrm{k}_{\mathrm{m}}$ and the filtration characteristics of the tested filtration fiber in the cylindrical form filter element based on the AP 019 by WIX Filtron of the following parameters [14]:
Przedmiotem badań była jedyna dostępna w tej chwili włóknina filtracyjna AC-301 firmy Korea Filtration Technologies Co. (tab. 1) ukształtowana w cylindrycznym wkładzie filtracyjnym.

Badania włókniny filtracyjnej przeprowadzono dla trzech wartości prędkości filtracji odpowiadających odpowiednio: prędkości filtracji typowej dla papierów filtracyjnych $v_{\mathrm{F} 1}=0,08 \mathrm{~m} / \mathrm{s}$, prędkości zbliżonej do podawanej (przez firmę Mann+Hummel) jako maksymalna dla włóknin filtracyjnych $\mathrm{v}_{\mathrm{F} 3}=0,27 \mathrm{~m} / \mathrm{s}$ oraz prędkości pośredniej $\mathrm{v}_{\mathrm{F} 2}=$ $=0,17 \mathrm{~m} / \mathrm{s}$.

Badania prowadzono do chwili osiągnięcia przez wkład filtracyjny założonej wartości oporu dopuszczalnego co najmniej $\Delta \mathrm{p}_{\text {fdop }}=5 \mathrm{kPa}$, a następnie z zależności (1) obliczano współczynnik chłonności pyłowej $\mathrm{k}_{\mathrm{m}}$ włókniny filtracyjnej.

Table 1. Parameters of the tested filtration fiber [8]

Tabela 1. Parametry badanej włókniny filtracyjnej [8]

\begin{tabular}{|l|c|c|}
\hline Parameter/parametr & Unit/jednostka & Value/wartość \\
\hline Gramature/gramatura & {$\left[\mathrm{g} / \mathrm{m}^{2}\right]$} & $210 \pm 10 \%$ \\
\hline Thickness/grubość & {$[\mathrm{mm}]$} & $2.34-2.86$ \\
\hline $\begin{array}{l}\text { Air permeability/ } \\
\text { przepuszczalnośc } \\
\text { powietrza }\end{array}$ & {$\left[\mathrm{cm}^{3} / \mathrm{cm}^{2} / \mathrm{s}\right]$} & $80-110$ at $120 \mathrm{~Pa}$ \\
\hline $\begin{array}{l}\text { Resistance to stret- } \\
\text { ching/wytrzymałość } \\
\text { na rozciaganie }\end{array}$ & {$[\mathrm{N} / 50 \mathrm{~mm}]$} & $>98$ \\
\hline $\begin{array}{l}\text { Resistance to ben- } \\
\text { ding/wytrzymałość } n a \\
\text { zginanie }\end{array}$ & {$[\mathrm{N} / 30 \mathrm{~mm}]$} & $1.47-2.94$ \\
\hline
\end{tabular}

\section{Metodyka i warunki badań włókniny filtracyjnej}

W celu określenia wartości współczynnika chłonności pyłu $\mathrm{k}_{\mathrm{m}}$ niezbędna jest znajomość masy pyłu mWF zatrzymanego na powierzchni włókniny filtracyjnej do osiągnięcia przyjętego oporu dopuszczalnego $\Delta \mathrm{p}_{\text {fdop }}$.

Badania przeprowadzono na stanowisku (rys. 3), którego głównymi elementami są cylindryczny wkład filtracyjny, wykonany z badanej włókniny filtracyjnej, umieszczony w metalowej obudowie, dozownik pyłu, przewód pomiarowy, manometr cieczowy i filtr absolutny. Stanowisko pomiarowe wyposażone zostało w licznik cząstek stałych Pamas-2132 z sensorem HCB-LD-2A-2000-1, który wykonuje analizę granulometryczną cząstek stałych znajdujących się w strumieniu powietrza, przy wykorzystaniu zjawiska rozpraszania wiązki promieniowania laserowego o długości fali $680 \mathrm{~nm}$. Licznik rejestruje liczbę oraz rozmiar ziaren pyłu w strumieniu powietrza, obejmując ich średnice z zakresu 0,7-100 $\mu \mathrm{m}$ w $\mathrm{i}=32$ przedziałach pomiarowych, będących zakresami ograniczonymi średnicami $\left(\mathrm{d}_{\text {zimin }}-\mathrm{d}_{\text {zimax }}\right)$. Szerokości przedziałów pomiarowych można zaprogramować dowolnie. Sensor urządzenia przystosowany jest do pracy przy maksymalnej koncentracji cząstek zanieczyszczeń w powietrzu do $1000 \mathrm{szt} . / \mathrm{ml}$, co odpowiada masowemu stężeniu zapylenia powietrza $\mathrm{s} \sim 0,25 \mathrm{~g} / \mathrm{m}^{3}$. Rejestracja ziaren znajdujących się w strumieniu zassanego powietrza nastę- 


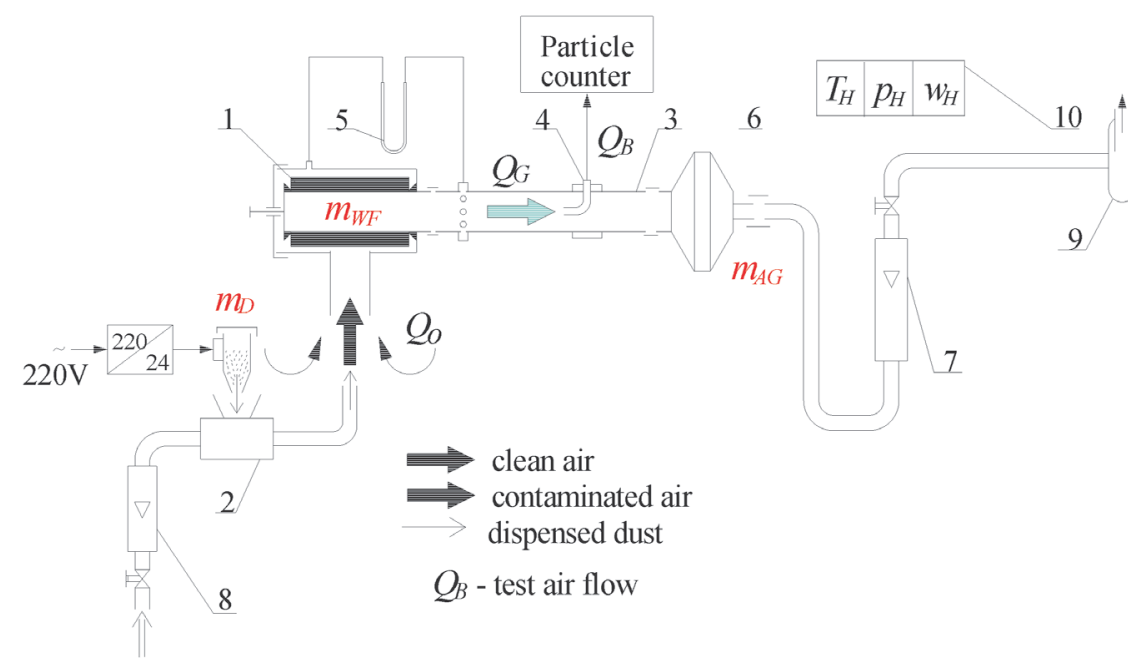

Fig. 3. Functional schematics of the filtration fiber test stand: 1 - test filter element, 2 - dust dispenser, 3 - measurement dust, 4 - dust probe, 5 - rotameter, 6 - absolute filter of the main duct, 7 - rotameter of the main airflow, 8 - rotameter of the compressed air, 9 - suction fan, 10 - thermohigrobarometer

Rys. 3. Schemat funkcjonalny stanowiska do badań włóknin filtracyjnych: 1 - wkład badawczy,

2 -dozownik pylu, 3 - przewód pomiarowy, 4-sonda pyłowa, 5-manometr cieczowy, 6-filtr absolutny przewodu głównego, 7 -rotametr strumienia głównego, 8-rotametr sprężonego powietrza, 9 -wentylator ssawny, 10 - termohigrobarometr

- Outer diameter of the filter element, $\mathrm{D}_{\mathrm{p}}=72 \mathrm{~mm}$,

- Pleat height, $\mathrm{b}_{\mathrm{p}}=10 \mathrm{~mm}$,

- Number of pleats, $i_{p}=14$,

- Active height of the fiber, $\mathrm{h}_{\mathrm{cz}}=116 \mathrm{~mm}$,

- Total filter element height, $\mathrm{H}_{\mathrm{w}}=140 \mathrm{~mm}$,

- Active area of the fiber surface $F_{w}=0.036 \mathrm{~m}^{2}$.

Filtration characteristics (filtration efficiency, drag, filtration accuracy) of the tested filtration fiber were determined according to relations (2) and (3) in the subsequent measurement cycles of a defined duration of $\tau_{\mathrm{I}}=3 \mathrm{~min}$ in the initial period of filtration and $\tau_{\mathrm{I}}=6 \mathrm{~min}$ in the outstanding period of the cleaner operation. In the last minute of the measurement cycle the number and size of the dust grains in the airflow downstream of the filter were measured. The dust concentration in the airflow was maintained at the level of $\mathrm{s}=0.5 \mathrm{~g} / \mathrm{m}^{3}$ using test dust PTC-D a local replacement dust type for the AC-fine dust whose chemical and granulometric composition is given in [10].

\section{Analysis of the research results}

The results of the research on the efficiency and accuracy of the filtration and the filter drag as a function of dust absorption coefficient $\mathrm{k}_{\mathrm{m}}$ of the filter element made from filtration fiber, operating at three different filtration rates $v_{F}$ have been presented in Figs 4 and 5.

In terms of the values of filtration efficiency we can divide the operating life of the tested fibers into three periods. The first (I), characterized by low filtration efficiency that gradually and abruptly grows as the mass of dust trapped in the filter element increases. This period is referred to as the period of non-steady operation, lasting from the moment of initiation of the filtration process until the maximum steady filtration efficiency is reached. The next period (steady puje w cyklu pomiarowym, w czasie którego można zaprogramować kilka zliczeń ziaren pyłu. Wyniki pomiarów przedstawiane są w postaci tabel (tyle tabel, ile zaprogramowano zliczeń) zawierających liczby $\mathrm{N}_{\mathrm{i}}$ ziaren pyłu objętych przedziałami pomiarowymi średnic $\left(\mathrm{d}_{\text {zimin }}-\mathrm{d}_{\text {zimax }}\right)$. W odpowiedniej odległości za badanym wkładem filtracyjnym umieszczona jest centralnie w osi przewodu końcówka sondy pomiarowej skierowana otworem wlotowym w stronę napływu strumienia zanieczyszczonego powietrza Q.

Przewód pomiarowy 3 zakończony jest filtrem absolutnym, który zabezpiecza przed przedostawaniem się pyłu (przepuszczonego przez wkład filtracyjny) do rotametru.

Zaproponowana metodyka umożliwia wyznaczenie współczynnika $\mathrm{k}_{\mathrm{m}}$ oraz charakterystyk filtracyjnych włókniny filtracyjnej badanej w postaci cylindrycznego wkładu badawczego, wykonanego na bazie wkładu filtracyjnego AP 019 firmy WIX Filtron o następujących parametrach [14]:

- średnica zewnętrzna wkładu, $\mathrm{D}_{\mathrm{p}}=72 \mathrm{~mm}$,

- wysokość plisy, $\mathrm{b}_{\mathrm{p}}=10 \mathrm{~mm}$

- liczba plis, $\mathrm{i}_{\mathrm{p}}=14$,

- wysokość czynna włókniny, $\mathrm{h}_{\mathrm{cz}}=116 \mathrm{~mm}$,

- całkowita wysokość wkładu, $\mathrm{H}_{\mathrm{w}}=140 \mathrm{~mm}$,

- powierzchnia czynna włókniny $\mathrm{F}_{\mathrm{w}}=0,036 \mathrm{~m}^{2}$.

Charakterystyki filtracyjne (skuteczność filtracji, opór przepływu, dokładność filtracji) badanej włókniny filtracyjnej określano zgodnie z zależnościami (2) i (3) w kolejnych cyklach pomiarowych o określonym czasie trwania wynoszącym: $\tau_{\mathrm{I}}=3 \mathrm{~min} \mathrm{w}$ początkowym okresie filtracji i $\tau_{\mathrm{I}}=6 \mathrm{~min}$ w pozostałym okresie pracy wkładu filtracyjnego. W ostatniej minucie cyklu pomiarowego dokonywano pomiaru liczby i rozmiaru ziaren pyłu w strumieniu powietrza za wkładem filtracyjnym. Utrzymywano stężenie zapylenia powietrza $\mathrm{s}=0,5 \mathrm{~g} / \mathrm{m}^{3}$, stosując pył testowy PTC-D, będący krajowym zamiennikiem pyłu AC-fine, którego skład chemiczny i granulometryczny podano w PN [10].

\section{Analiza wyników badań}

Wyniki badań charakterystyk: skuteczności i dokładności filtracji oraz oporów przepływu w funkcji współczynnika chłonności pyłu $\mathrm{k}_{\mathrm{m}}$ wkładu filtracyjnego wykonanego z włókniny filtracyjnej, pracującego przy trzech różnych prędkościach filtracji $\mathrm{U}_{\mathrm{F}}$, przedstawiono na rys. 4 i 5.

Ze względu na osiągane wartości skuteczności filtracji, czas pracy badanych włóknin można podzielić umownie na trzy okresy. Pierwszy (I) - charakteryzuje się małymi wartościami skuteczności filtracji, które systematycznie i gwałtownie wzrastają wraz z ilością masy pyłu zatrzymanego przez włókninę. Okres ten w literaturze jest nazywany 
state filtration) is characterized with high (above $99 \%$ ) and continuously and slowly growing filtration efficiency. In the case of the tested fibers a separation point between the two periods was adopted at the filtration efficiency of $\varphi_{\mathrm{w}}=$ $=99.5 \%$. After the first measurement cycle the efficiency of the tested fibers reaches approx. $95 \%$ (Fig. 4). At this time in the air cleaned by the filter elements dust was observed containing grains of the size below $\mathrm{d}_{\mathrm{zmax}}=15-28 \mu \mathrm{m}$ and the greater values pertain to the filter element operating at higher filtration rates. With each measurement cycle the number of dust grains and their size $\mathrm{d}_{\mathrm{zmax}}$ in the processed air drops until zero. It was assumed that the largest grain $\mathrm{d}_{\mathrm{zmax}}$ in the airflow downstream of the air cleaner expresses the accuracy of the filtration in the subsequent measurement cycle.

In each subsequent cycle the filtration efficiency of the tested fibers reaches greater values (Fig. 4) and the sizes of the grains in the processed air and their number are getting smaller and, for coefficient $\mathrm{k}_{\mathrm{m}}=72-91 \mathrm{~g} / \mathrm{m}^{2}$, they stabilize on the level of $\mathrm{d}_{\mathrm{zmax}}=6.2-11.8 \mu \mathrm{m}$ (Fig. 5). Then the main (II) period of the filter element operation initiates lasting until the moment the filtration accuracy and efficiency drops (different for various filtration rates). The third (III) period of operation of the filtration fibers is characterized by a slow drop in the filtration efficiency and the appearance of larger dust grains $\left(\mathrm{d}_{\mathrm{zmax}}=12.6 \mu \mathrm{m}\right)$ downstream of the filter element.

In the case of the tested fibers a separation point of the periods was adopted as of the moment of the filtration fiber reaching the filtration efficiency of $\varphi_{\mathrm{w}}=99.5 \%$. This value, at the filtration rate $v_{F}=0.27 \mathrm{~m} / \mathrm{s}$, was obtained by the fiber at the dust absorption coefficient $\mathrm{k}_{\mathrm{m}}=240.5 \mathrm{~g} / \mathrm{m}^{3}$. The lower the filtration rate the greater the value of coefficient $\mathrm{k}_{\mathrm{m}}$ at which the efficiency drop occurs. At the filtration rate of $\mathrm{v}_{\mathrm{F}}=0.17 \mathrm{~m} / \mathrm{s}-\mathrm{k}_{\mathrm{m}}=297.3 \mathrm{~g} / \mathrm{m}^{3}$ and $\mathrm{v}_{\mathrm{F}}=0.08 \mathrm{~m} / \mathrm{s}-\mathrm{k}_{\mathrm{m}}=$ $=350.5 \mathrm{~g} / \mathrm{m}^{3}$.

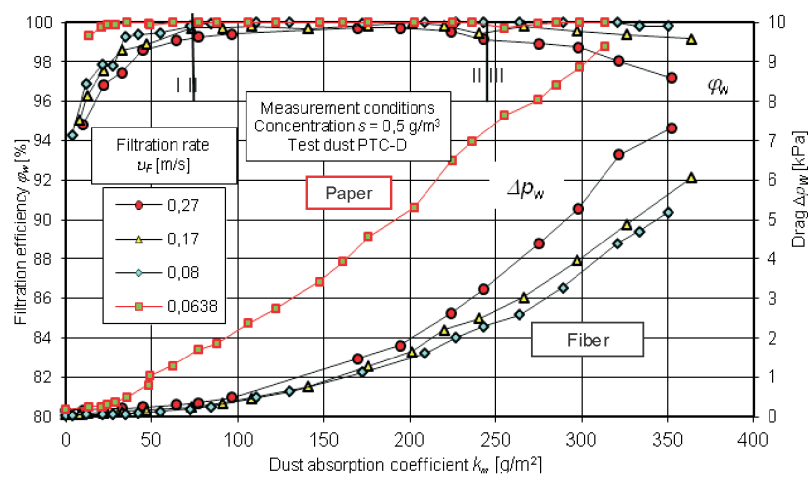

Fig. 4. Filtration efficiency $\varphi_{\mathrm{w}}=\mathrm{f}\left(\mathrm{k}_{\mathrm{m}}\right)$ and filter drag $\Delta \mathrm{p}_{\mathrm{w}}=\mathrm{f}\left(\mathrm{k}_{\mathrm{m}}\right)$ characteristics as a function of dust absorption coefficient $\mathrm{k}_{\mathrm{m}}$ of the fiber filter element

Rys. 4. Charakterystyki skuteczności filtracji $\varphi_{w}=f\left(k_{m}\right)$ i oporu przepływu $\Delta p_{w}=f\left(k_{m}\right)$ w funkcji współczynnika chłonności pyłowej $k_{m}$ wkładu filtracyjnego włókninowego

As the mass of the dust trapped in the fiber grows, drag $\Delta \mathrm{p}_{\mathrm{w}}$ of the tested fiber increases steadily and the rate of increment of drag $\Delta \mathrm{p}_{\mathrm{w}}$ of the tested filter element grows with filtration rate $v_{F}$. The fastest growth in the drag was observed okresem filtracji nieustalonej, trwa od chwili rozpoczęcia procesu filtracji do osiągnięcia przez materiał filtracyjny maksymalnej ustalonej wartości skuteczności filtracji. Następujący po nim okres (filtracji ustalonej) charakteryzuje się dużymi (powyżej 99 \%) i ciągle, ale powolnie rosnącymi wartościami skuteczności filtracji. Dla badanych włóknin przyjęto strefę rozdziału obu okresów z chwilą uzyskania przez włókninę skuteczności filtracji $\varphi_{\mathrm{w}}=99,5 \%$. Po pierwszym cyklu pomiarowym skuteczność badanych włóknin przyjmuje wartości około $95 \%$ (rys 4). W tym czasie w powietrzu oczyszczonym przez wkłady filtracyjne znajdował się pył zawierający ziarna o rozmiarach ziaren poniżej $\mathrm{d}_{\mathrm{zmax}}=15-28 \mu \mathrm{m}$, przy czym wyższe wartości dotyczą pracy wkładu przy wyższych prędkościach filtracji. Z każdym cyklem badawczym liczba ziaren pyłu oraz ich rozmiar $\mathrm{d}_{\mathrm{zmax}}$ w powietrzu oczyszczonym maleje, aż do ich całkowitego zaniku. Przyjęto, że ziarno pyłu o największym rozmiarze $\mathrm{d}_{\text {zmax }}$ znajdujące się w strumieniu powietrza wylotowego z badawczego wkładu filtracyjnego wyraża dokładność filtracji w kolejnym cyklu pomiarowym.

W każdym następnym cyklu pomiarowym skuteczność filtracji badanych włóknin przyjmuje coraz większe wartości (rys. 4), a rozmiary ziaren pyłu w powietrzu oczyszczonym i ich liczba są coraz mniejsze i dla współczynnika $\mathrm{k}_{\mathrm{m}}=72-91 \mathrm{~g} / \mathrm{m}^{2}$ stabilizują się na poziomie $\mathrm{d}_{\mathrm{zmax}}=6,2-11,8 \mu \mathrm{m}$ (rys. 5). Rozpoczyna się wówczas zasadniczy (II) okres pracy wkładu, trwający do chwili spadku dokładności i skuteczności filtracji, który dla każdej prędkości filtracji jest inny. Trzeci (III) okres pracy włóknin charakteryzuje się więc powolnym spadkiem skuteczności filtracji i pojawianiem się w strumieniu powietrza za wkładem badawczym coraz większych $\left(\mathrm{d}_{\mathrm{z} \max }=12,6 \mu \mathrm{m}\right)$ ziaren pyłu.

W odniesieniu do badanych włóknin przyjęto strefę rozdziału obu okresów z chwilą uzyskania przez włókninę skuteczności filtracji $\varphi_{\mathrm{w}}=99,5 \%$. Wartość tę włóknina badana przy prędkości filtracji $v_{\mathrm{F}}=0,27 \mathrm{~m} / \mathrm{s}$ osiągnęła przy współczynniku chłonności pyłu $\mathrm{k}_{\mathrm{m}}=240,5 \mathrm{~g} / \mathrm{m}^{3}$. Im mniejsza prędkość filtracji, tym spadek skuteczności występuje przy większej wartości współczynniku $\mathrm{k}_{\mathrm{m}}$. Przy prędkości filtracji

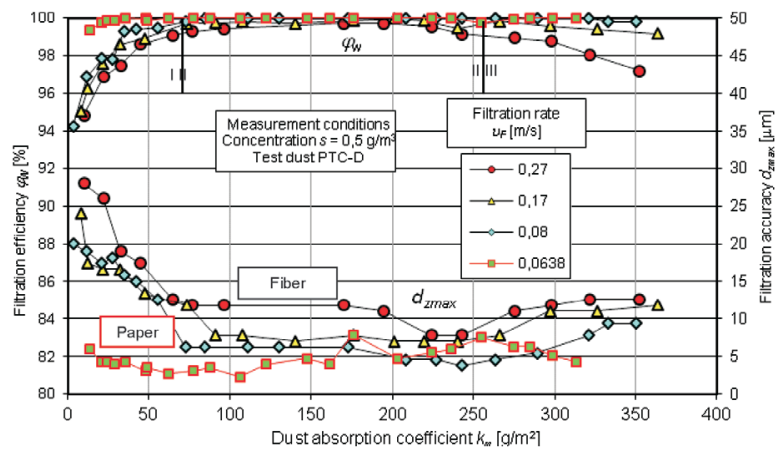

Fig. 5. Filtration accuracy $\mathrm{d}_{\mathrm{zmax}}=\mathrm{f}\left(\mathrm{k}_{\mathrm{m}}\right)$ and filtration efficiency $\varphi_{\mathrm{w}}=\mathrm{f}\left(\mathrm{k}_{\mathrm{m}}\right)$ characteristics as a function of dust absorption coefficient $\mathrm{k}_{\mathrm{m}}$ of the fiber filter element

Rys. 5. Charakterystyki doktadności filtracji $d_{z \max }=f\left(k_{m}\right)$ oraz skuteczności filtracji $\varphi_{w}=f\left(k_{m}\right)$ w funkcji wspótczynnika chłonności pyłowej $k_{m}$ wkładu filtracyjnego włókninowego 
at the filtration rate of $\mathrm{v}_{\mathrm{F}}=0.27 \mathrm{~m} / \mathrm{s}$ and the slowest at the rate of $v_{F}=0.08 \mathrm{~m} / \mathrm{s}$, which is in line with the general conditions of flow through a porous barrier. As the predefined drag of $\Delta \mathrm{p}_{\mathrm{w}}=5 \mathrm{kPa}$ is reached the filter elements has trapped dust mass determining dust absorption coefficient $\mathrm{k}_{\mathrm{m}}$ of the tested fiber on the level of $\mathrm{k}_{\mathrm{m}}=290 \mathrm{~g} / \mathrm{m}^{2}$ at the filtration rate $v_{\mathrm{F}}=0.27 \mathrm{~m} / \mathrm{s}$, at $\mathrm{v}_{\mathrm{F}}=0.17 \mathrm{~m} / \mathrm{s}-\mathrm{k}_{\mathrm{m}}=330 \mathrm{~g} / \mathrm{m}^{2}$ and at $\mathrm{v}_{\mathrm{F}}=$ $=0.08 \mathrm{~m} / \mathrm{s}-\mathrm{k}_{\mathrm{m}}=343 \mathrm{~g} / \mathrm{m}^{2}$. Hence, a reduction in the filtration rate from $v_{\mathrm{F}}=0.27 \mathrm{~m} / \mathrm{s}$ to $v_{\mathrm{F}}=0.08 \mathrm{~m} / \mathrm{s}$ resulted in an increase in absorption coefficient $\mathrm{k}_{\mathrm{m}}$ by $18 \%$.

Such a cause of the characteristics of efficiency and accuracy of filtration must be explained by the fact that the grains of dust trapped in the barrier are a source of secondary components of the filtration material. The subsequent dust grains deposit not only on the fibers but also on the previously trapped grains. Large agglomerates are generated that fill the empty space between the fibers (Fig. 6), which results in smaller grains being trapped and an obstruction of aerosol flow, which explains the increase in the drag with the growing mass of the trapped dust.

a)

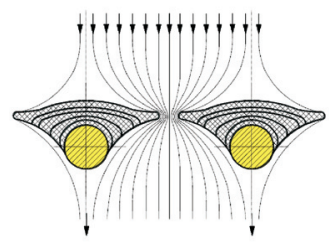

b)
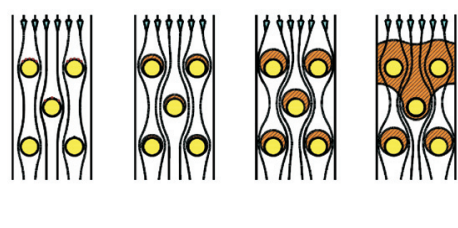

Fig. 6. Changes in the structure of the filtration layer as a result of trapping of the dust grains: a) on individual fibers, b) inside the filtration layer $[4,8]$

Rys. 6. Zmiany struktury warstwy filtracyjnej wskutek zatrzymywania ziaren pytu: a) na pojedynczych wtóknach, b) wewnątrz warstwy filtracyjnej $[4,8]$

A reduction in the filtration accuracy upon trapping by the filter of a given dust mass manifests through the appearance in the processed air of dust grains of the size greater than those in the II period of the filter element operation. This phenomenon can be explained by the effect of 'penetration' consisting in detaching from the surface (as a result of high flow rates) of grains and their agglomerates and moving inside the material as far as to the outlet side of the filtration material. Grabbing of the previously trapped dust grains by the airflow is more likely if the flow rates are higher, hence the highest accuracy (the smallest size the maximum dust grains $\mathrm{d}_{\mathrm{zmax}}=3.8 \mu \mathrm{m}$ ) in the main period of operation of the filter element was observed for the rate of $v_{F}=0.08 \mathrm{~m} / \mathrm{s}$, and the lowest $\left(\mathrm{d}_{\mathrm{zmax}}=7 \mu \mathrm{m}\right)$ for $\mathrm{v}_{\mathrm{F}}=0.27 \mathrm{~m} / \mathrm{s}$. Figures 4 and 5 show (for comparison) the results of analogical tests [4] performed with the use of filtration paper whose parameters have been presented in Table 2 .

The paper filter element is characterized with better filtration accuracy and efficiency characteristics. The efficiency of the filtration of a paper filter element exceeds $99 \%$ already in the beginning of its operation and then it grows to $99.9 \%$ and maintains on this level throughout the entire time of
$\mathrm{v}_{\mathrm{F}}=0,17 \mathrm{~m} / \mathrm{s}-\mathrm{k}_{\mathrm{m}}=297,3 \mathrm{~g} / \mathrm{m}^{3}$, a przy $\mathrm{v}_{\mathrm{F}}=0,08 \mathrm{~m} / \mathrm{s}-$ $\mathrm{k}_{\mathrm{m}}=350,5 \mathrm{~g} / \mathrm{m}^{3}$.

Wraz ze wzrostem masy pyłu zatrzymanego przez włókninę filtracyjną, opór przepływu $\Delta \mathrm{p}_{\mathrm{w}}$ badanych włóknin filtracyjnych cały czas systematycznie rośnie, przy czym intensywność narastania oporu przepływu $\Delta \mathrm{p}_{\mathrm{w}}$ badanych wkładów zwiększa się wraz ze wzrostem prędkości filtracji $v_{\mathrm{F}}$. Najszybszy wzrost oporów przepływu zaobserwowano przy prędkości filtracji $v_{\mathrm{F}}=0,27 \mathrm{~m} / \mathrm{s}$, a najwolniejszy przy prędkości filtracji $v_{\mathrm{F}}=0,08 \mathrm{~m} / \mathrm{s}$, co jest zgodne $\mathrm{z}$ ogólnymi warunkami przepływu przez przegrodę porowatą. $\mathrm{Z}$ chwilą osiągnięcia ustalonego oporu przepływu $\Delta \mathrm{p}_{\mathrm{w}}=5 \mathrm{kPa}$ na wkładzie filtracyjnym została zatrzymana masa pyłu, określajaca współczynnik chłonności pyłowej $\mathrm{k}_{\mathrm{m}}$ badanej włókniny na poziomie $\mathrm{k}_{\mathrm{m}}=290 \mathrm{~g} / \mathrm{m}^{2}$ przy prędkości filtracji $v_{\mathrm{F}}=0,27 \mathrm{~m} / \mathrm{s}$, przy $v_{\mathrm{F}}=0,17 \mathrm{~m} / \mathrm{s}-\mathrm{k}_{\mathrm{m}}=330 \mathrm{~g} / \mathrm{m}^{2}$ oraz przy $\mathrm{v}_{\mathrm{F}}=0,08 \mathrm{~m} / \mathrm{s}-\mathrm{k}_{\mathrm{m}}=343 \mathrm{~g} / \mathrm{m}^{2}$. Zatem zmniejszenie prędkości filtracji $\mathrm{z} \mathrm{v}_{\mathrm{F}}=0,27 \mathrm{~m} / \mathrm{s}$ do $\mathrm{v}_{\mathrm{F}}=0,08 \mathrm{~m} / \mathrm{s}$ spowodowało wzrost współczynnika chłonności $\mathrm{k}_{\mathrm{m}} \mathrm{o} 18 \%$.

Taki przebieg charakterystyk skuteczności i dokładności filtracji oraz oporów przepływu należy tłumaczyć tym, że zatrzymane w przegrodzie ziarna pyłu są źródłem powstawania wtórnych elementów struktury materiału filtracyjnego. Kolejne ziarna pyłu osiadają nie tylko na włóknach, ale również na wcześniej zatrzymanych ziarnach. Powstają rozrastające się często do znacznych rozmiarów aglomeraty, które wypełniają wolne przestrzenie między włóknami (rys. 6), co powoduje, że zatrzymywane są coraz mniejsze ziarna, ale jednocześnie następuje utrudniony przepływ aerozolu, czym należy tłumaczyć wzrost oporów przepływu wraz ze wzrostem masy zatrzymanego przez wkłady pyłu.

Zmniejszenie dokładności filtracji po zatrzymaniu przez wkład określonej masy pyłu uwidacznia się pojawianiem w strumieniu oczyszczonego powietrza ziaren pyłu o rozmiarach powyżej wartości, jakie występowały dla II zasadniczego okresu pracy wkładu. Zjawisko to tłumaczyć można wystąpieniem tzw. zjawiska „przebicia”, które polega na odrywaniu się od podłoża (w wyniku dużych prędkości przepływu) ziaren pyłu oraz całych ich aglomeratów i przemieszczaniu w głąb materiału, aż na stronę wylotową materiału filtracyjnego. Porywanie przez strumień powietrza zatrzymanych wcześniej ziaren pyłu jest bardziej prawdopodobne przy większych prędkościach przepływu, stąd najwyższą dokładność (najmniejszy rozmiar maksymalnych ziaren pyłu $\mathrm{d}_{\mathrm{zmax}}=3,8 \mu \mathrm{m}$ ) w okresie zasadniczym pracy wkładu zaobserwowano przy prędkości filtracji $v_{\mathrm{F}}=0,08 \mathrm{~m} / \mathrm{s}$, a najniższą $\left(\mathrm{d}_{\mathrm{zmax}}=7 \mu \mathrm{m}\right)$ przy $v_{\mathrm{F}}=0,27 \mathrm{~m} / \mathrm{s}$. Na rysunkach 4 i 5 naniesiono (celem porównania) wyniki analogicznych badań [5], przeprowadzonych z wykorzystaniem papieru filtracyjnego, którego parametry przedstawiono w tab. 2 .

Wkład wykonany z papieru filtracyjnego cechuje korzystniejszy przebieg charakterystyki dokładności i skuteczności filtracji. Skuteczność filtracji papierowego wkładu filtracyjnego już na początku jego pracy przekracza $99 \%$, po czym wzrasta do $99,9 \%$ i utrzymuje się na tym poziomie w dalszym okresie jego pracy. W początkowym okresie pracy wkładu rozmiar maksymalnych ziaren pyłu nie przekracza wartości $\mathrm{d}_{\mathrm{zmax}}=5,9 \mu \mathrm{m}$, 
operation. In the initial period of the filter element operation the size of the maximum dust grains does not exceed $\mathrm{d}_{\mathrm{zmax}}=$ $=5.9 \mu \mathrm{m}$ and then it stabilizes on the level $\mathrm{d}_{\mathrm{zmax}}=2.3-3.9 \mu \mathrm{m}$ and in the final period operation grains of the size of $\mathrm{d}_{\mathrm{zmax}}=$ $=7.5 \mu \mathrm{m}$ appear in the airflow.

Along the increase in the mass of dust trapped by the filtering paper, systematically grows drag $\Delta \mathrm{p}_{\mathrm{w}}$ of the tested filter element and the rate of increment is greater than the previously analyzed fiber filter elements. At drag $\Delta \mathrm{p}_{\mathrm{w}}=$ $=5 \mathrm{kPa}$ the value of dust absorption coefficient $\mathrm{k}_{\mathrm{m}}$ of the tested filtration paper is $190 \mathrm{~g} / \mathrm{m}^{2}$ - more than $140 \%$ less than in the case of the fiber filter element operating at similar filtration rate $v_{\mathrm{F}}=0.08 \mathrm{~m} / \mathrm{s}$.

In Figures 7-9 for the initial test cycles parentage changes have been presented of the share $U_{p}$ of dust grains of individual size groups in the total number of dust grains in the airflow for the test filter elements, made from paper and fiber respectively. In the initial period of operation of the filter elements the changes in the filtration accuracy are very intense. The presented results were obtained at similar filtration rates: $v_{F}=0.08 \mathrm{~m} / \mathrm{s}$ on the fiber filter element and $v_{F}=0.0638 \mathrm{~m} / \mathrm{s}$ on the paper filter element. Percentage share $\mathrm{U}_{\mathrm{pi}}$ has been determined from the relation:

$$
\mathrm{Up}_{\mathrm{i}}=\frac{\mathrm{N}_{\mathrm{i}}}{\mathrm{N}}=\frac{\mathrm{N}_{\mathrm{i}}}{\sum_{\mathrm{i}=1}^{32} \mathrm{~N}_{\mathrm{i}}}
$$

where: $\mathrm{N}_{\mathrm{i}}$ - number of dust grains from i-th size interval, $\mathrm{N}$ - total number of dust grains downstream of the filter element.

Along the increase in the dust mass trapped in the filter elements, a growth in the share of dust grains of the smallest size (below $1.4 \mu \mathrm{m}$ ) occurred in the airflow downstream of the filter element and a drop in the share of the dust grain size above $1.4 \mu \mathrm{m}$, which is in line with the theory of operation of filtration mechanisms in a porous barrier. During the first test cycle the share of particles below $0.7 \mu \mathrm{m}$ had the value of $\mathrm{U}_{\mathrm{p} 1}=43.26 \%$, during the third cycle this share increased to $\mathrm{U}_{\mathrm{p} 5}=57.92 \%$, and during the fifth to $\mathrm{U}_{\mathrm{p} 5}=68.56 \%$ (Fig. 7-9).

a)

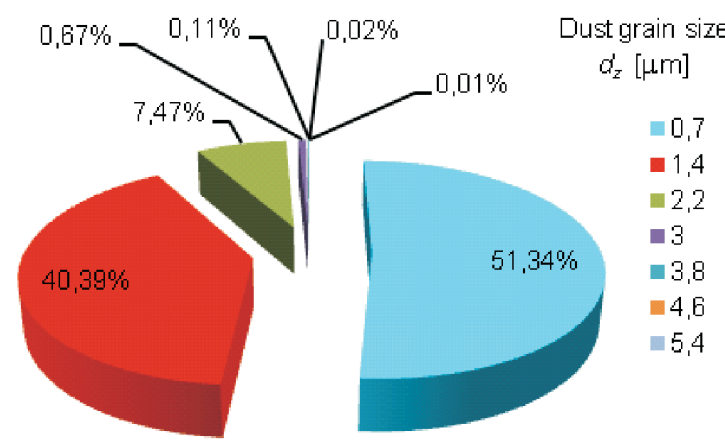

po czym stabilizuje się na poziomie $\mathrm{d}_{\text {zmax }}=2,3-3,9 \mu \mathrm{m}$, a w końcowym okresie pracy w strumieniu powietrza pojawiają się ziarna pyłu o rozmiarze $\mathrm{d}_{\mathrm{zmax}}=7,5 \mu \mathrm{m}$.

Table 2. Filtration paper parameters J.C. BINZER 796/1 VH 186 [4] Tabela 2. Parametry papieru filtracyjnego J.C. BINZER 796/1 VH 186 [4]

\begin{tabular}{|l|c|c|}
\hline Parameter/parametr & $\begin{array}{c}\text { Unit/ } \\
\text { jednostka }\end{array}$ & $\begin{array}{c}\text { Value/ } \\
\text { wartość }\end{array}$ \\
\hline Gramature/gramatura & $\mathrm{g} / \mathrm{m}^{2}$ & 204 \\
\hline Thickness/grubość & $\mathrm{mm}$ & 0.9 \\
\hline $\begin{array}{l}\text { Drag at/opór powietrza } \\
\text { przy } 400 \mathrm{~cm}^{3} / \mathrm{s}, \mathrm{A}=10 \mathrm{~cm}^{2}\end{array}$ & $\mathrm{kPa}$ & 0.67 \\
\hline $\begin{array}{l}\text { Resistance to tear/wytrzymatość na } \\
\text { rozrywanie }\end{array}$ & $\mathrm{kPa}$ & 385 \\
\hline Resin content/zawartość żywicy & $\%$ & 18.8 \\
\hline $\begin{array}{l}\text { Maximum value of the pore diameter/ } \\
\text { maksymalna wartość średnicy por }\end{array}$ & $\mu \mathrm{m}$ & 51 \\
\hline $\begin{array}{l}\text { Average value of the pore diameter/ } \\
\text { wartość średnia średnicy por }\end{array}$ & $\mu \mathrm{m}$ & 42 \\
\hline
\end{tabular}

Wraz ze wzrostem masy pyłu zatrzymanego przez papier filtracyjny opór przepływu $\Delta \mathrm{p}_{\mathrm{w}}$ badanego wkładu cały czas systematycznie rośnie, a intensywność wzrostu jest większa niż analizowanych wcześniej wkładów włókninowych. Przy oporze przepływu $\Delta \mathrm{p}_{\mathrm{w}}=5 \mathrm{kPa}$ wartość współczynnika chłonności pyłowej $\mathrm{k}_{\mathrm{m}}$ badanego papieru filtracyjnego wynosi $190 \mathrm{~g} / \mathrm{m}^{2}$, a więc o ponad $140 \%$ mniej niż dla włókniny filtracyjnej pracującej przy zbliżonej prędkości filtracji $\mathrm{v}_{\mathrm{F}}=0,08 \mathrm{~m} / \mathrm{s}$. Na rysunkach 7-9 przedstawiono dla początkowych cykli badawczych procentowe zmiany udziału $U_{p}$ ziaren pyłu poszczególnych grup wymiarowych w całkowitej liczbie ziaren pyłu w strumieniu powietrza za badawczymi wkładami filtracyjnymi, wykonanymi odpowiednio z włókniny oraz z papieru filtracyjnego. W początkowym okresie pracy wkładów zmiany dokładności filtracji są bardzo intensywne. Prezentowane wyniki uzyskano przy zbliżonych prędkościach filtracji: $v_{\mathrm{F}}=0,08 \mathrm{~m} / \mathrm{s}$ na wkładzie włókninowym oraz $v_{\mathrm{F}}=0,0638 \mathrm{~m} / \mathrm{s}$ dla wkładu z papieru filtracyjnego. Udział procentowy $\mathrm{U}_{\mathrm{pi}}$ określono z zależności (5), gdzie: $\mathrm{N}_{\mathrm{i}}$ - liczba ziaren pyłu z i-tego przedziału wymiarowego, $\mathrm{N}$ - całkowita liczba ziaren pyłu za wkładem filtracyjnym.

b)

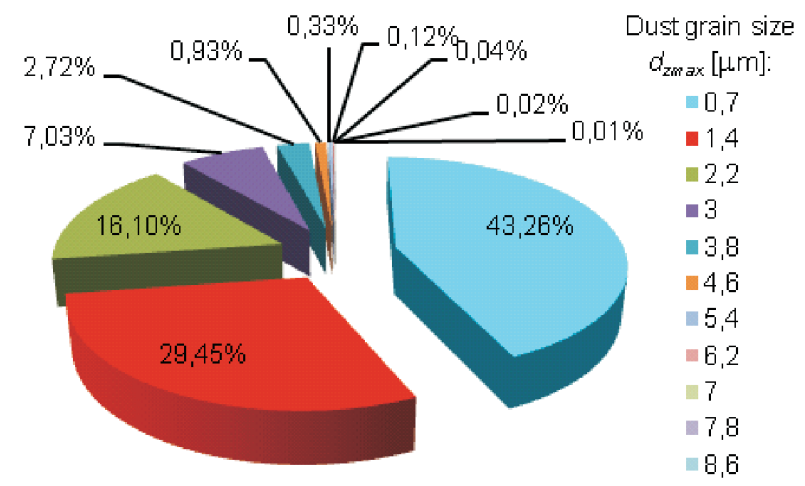

Fig. 7. Granulometric composition of dust during test cycle 1 downstream of the filter element: a) paper b) fiber Rys. 7. Skład granulometryczny pyłu podczas cyklu pomiarowego nr 1 za wkładem filtracyjnym: a) papierowym, b) włókninowym 
a)

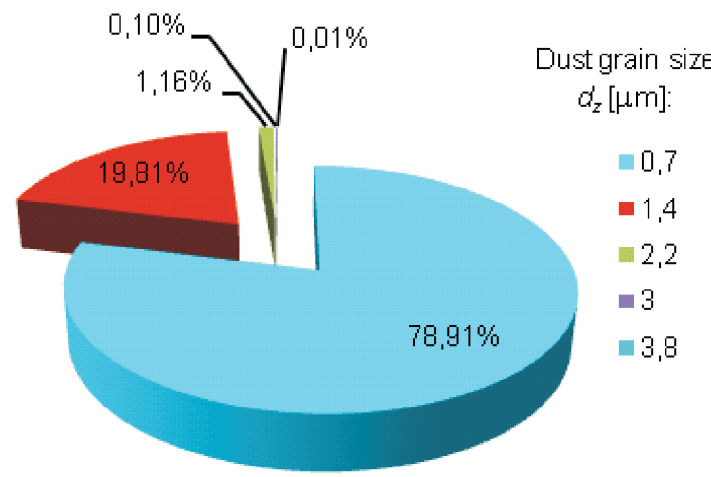

b)

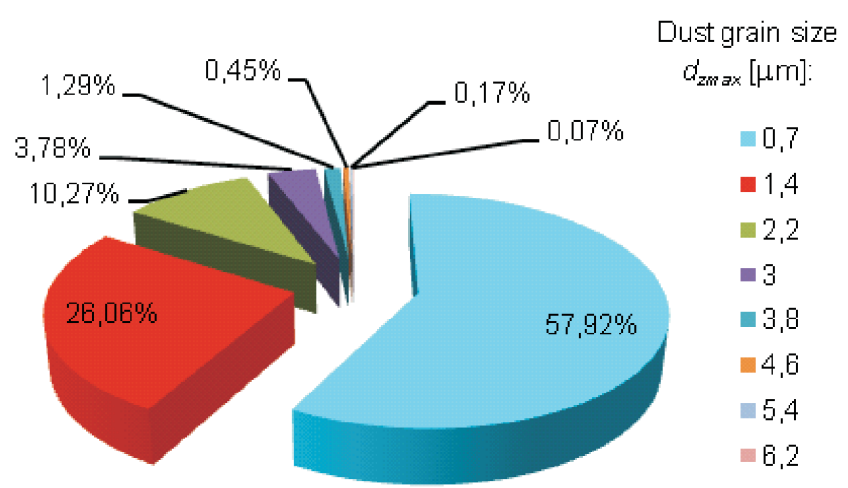

Fig. 8. Granulometric composition of dust during test cycle 3 downstream of the filter element: a) paper b) fiber Rys. 8. Skład granulometryczny pyłu podczas cyklu pomiarowego nr 3 za wkładem filtracyjnym: a) papierowym, b) włókninowym

a)

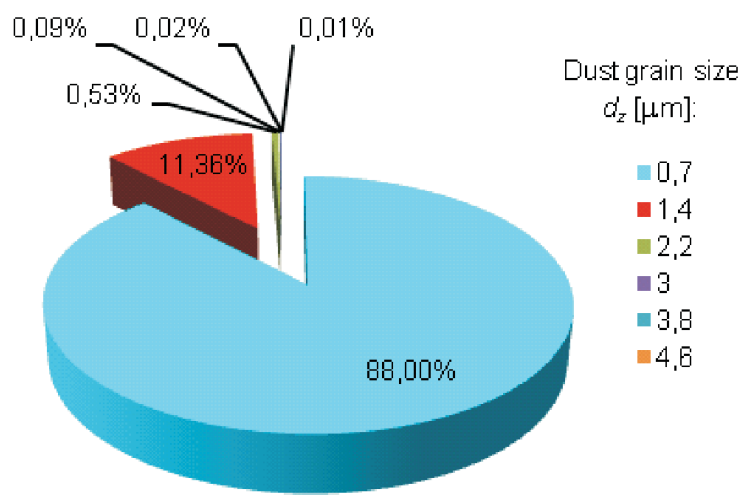

b)

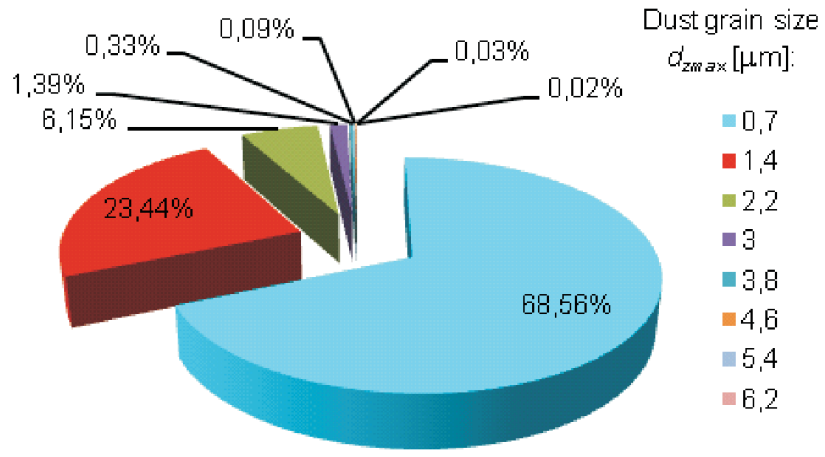

Fig. 9. Granulometric composition of dust during test cycle 5 downstream of the filter element: a) paper b) fiber Rys. 9. Skład granulometryczny pyłu podczas cyklu pomiarowego nr 5 za wkładem filtracyjnym: a) papierowym, b) włókninowym

The granulometric composition of dust downstream of the paper filter element changed analogically only the shares of particles below $0.7 \mu \mathrm{m}$ assumed greater values (Fig. 7-9). From the above it results that the filtration paper has better filtration efficiency and accuracy in trapping dust grains of the size greater than $1.4 \mu \mathrm{m}$ than it is in the case of the fiber structure. That is why the share of the dust grains of this size in the airflow downstream of the filter elements has lower values. During the first five test cycles the change in the shares (1.4-2.2 $\mu \mathrm{m})$ changed from $7.47 \%$ to $0.53 \%$ for the paper filter element and from $16.1 \%$ to $6.15 \%$ for the fiber structure filter element respectively.

\section{Conclusions}

1. Coefficient of dust absorption $\mathrm{k}_{\mathrm{m}}$ of the filtration fiber determined with the presented methodology for the filtration rates in the range $v_{\mathrm{F}}=0.08-0.27 \mathrm{~m} / \mathrm{s}$ assumes the values of $343-290 \mathrm{~g} / \mathrm{m}^{2}$. These values, determined with the same method are greater than those for the paper filter elements $\left(\mathrm{k}_{\mathrm{m}}=190 \mathrm{~g} / \mathrm{m}^{2}\right)$, which is caused by the three times greater thickness of the fiber structure.

2. The initial period of filtration in the case of the tested fibers is characterized by lower efficiency and accuracy
Wraz ze wzrostem masy pyłu zatrzymywanego na wkładzie filtracyjnym w strumieniu powietrza za badanymi wkładami następował wzrost udziału cząstek pyłu o najmniejszych rozmiarach (poniżej 1,4 $\mu \mathrm{m}$ ), a spadek udziałów ziaren pyłu o rozmiarach powyżej 1,4 $\mu \mathrm{m}$, co zgodne jest z teorią działania mechanizmów filtracji w przegrodzie porowatej. Podczas pierwszego cyklu badawczego udział cząstek poniżej 0,7 $\mu \mathrm{m}$ ma wartość $U_{\mathrm{pl}}=43,26 \%$, podczas trzeciego cyklu nastąpił wzrost do $U_{p 5}^{p 1}=57,92 \%$, a podczas piątego cyklu do $U_{p 5}=68,56 \%$ (rys. 7-9). Skład granulometryczny pyłu za papierowym wkładem filtracyjnym zmienia się w sposób analogiczny, ale udziały cząstek poniżej $0,7 \mu \mathrm{m}$ przyjmują odpowiednio większe wartości (rys. 7-9). Wynika z tego, że papier filtracyjny ma większą skuteczność i dokładność filtracji ziaren pyłu powyżej 1,4 $\mu \mathrm{m}$ niż struktura włókninowa. Dlatego udział ziaren pyłu o tych rozmiarach w strumieniu powietrza za wkładem papierowym ma mniejsze wartości. Podczas pierwszych pięciu cykli badawczych zmiana udziałów w zakresie 1,4-2,2 $\mu \mathrm{m}$ zmieniła się odpowiednio z 7,47 \% do $0,53 \% \mathrm{w}$ przypadku wkładu filtracyjnego papierowego i z $16,10 \%$ do $6,15 \%$ w przypadku wkładu włókninowego. 
than it is in the case of the paper filter element and the time needed to reach the assumed efficiency $(99.5 \%)$ is four times longer. This phenomenon may take place when the vehicle is operated after a filter element renewal and may be a reason for accelerated wear of the engine components thus, leading to a reduction of its life.

3. The lower the filtration rate of the fibers the smaller the size of the maximum dust grains $\mathrm{d}_{\mathrm{zmax}}$ and at the filtration rate of $v_{\mathrm{F}}=0.08 \mathrm{~m} / \mathrm{s}$ they do not exceed $\mathrm{d}_{\mathrm{zmax}}=19 \mu \mathrm{m}$ in the initial period of filtration and $\mathrm{d}_{\mathrm{zmax}}=3.8 \mu \mathrm{m}$ in the steady-state filtration.

4. The appearance of dust grains of greater size downstream of the tested filter element in the final stage of its life results from the phenomenon referred to as 'penetration' that is caused by intense airflow though the filtration medium already filled with dust. This is not a mass effect, it pertains to single grains and does not occur on a regular basis.

5. The tested filtration fiber structure for the filtration conditions similar to those of the paper filter element is characterized by a slightly worse filtration efficiency and accuracy (which is confirmed by the granulometric composition of dust in the airflow downstream of the tested filter elements) but the dust absorption is twice as high.

6. A verification is advised of the criteria of selection of the fibers for the filtration barri ers in motor vehicle engines and the application of fiber filter elements only for the filtration rates not exceeding $v_{\mathrm{F}}=0.08 \mathrm{~m} / \mathrm{s}$.

\section{Bibliography/Literatura}

[1] Baczewski K., Hebda M.: Filtracja płynów eksploatacyjnych, MCNEMT, Radom 1991/92.

[2] Braun R., Sauter H., Seggern J., Enderich A.: Engine air filtration. MTZ, 67, 2006.

[3] Durst M., Klein G., Moser N.: Filtration in Fahrzeugen. Materiały informacyjne firmy Mann+Hummel GMBH, Ludwigsburg, Niemcy 2005.

[4] Dziubak T.: Filtracja powietrza wlotowego do silników spalinowych pojazdów mechanicznych, WAT, Warszawa 2012.

[5] Dziubak T.: Analiza procesu filtracji powietrza wlotowego do silników pojazdów specjalnych. WAT, Warszawa 2008.

[6] Dziubak T., Szwedkowicz S.: Badania eksperymentalne papieru filtracyjnego pracującego w systemie ,cyklon - przegroda porowata”. Biuletyn WAT, vol LXII, nr 1, 2013.

[7] Erdmannsdörfer H.: Trocklenluftfilter für FahrzeugmotorenAuslegungs - und Leistungsdaten, MTZ, 43, nr 7/8, 1982.

[8] Korea Filtration Technologies Co.: Performance mill sheet, materiały udostępnione przez WIX Filtron, Gostyń.

[9] Nietzold I.: Filtracja powietrza, Arkady, Warszawa 1984.

[10] PN-S-34040, Filtry powietrza. Wymagania i badania, PKN, 1996.

[11] Sanders R., Bühler A., Durst M., Moser N., Pelz A.: Effiziente Motorluftfiltration durch den Einsatz von Nanofasern, MTZ 68, no. 2, 2007.

[12] Taufkirch G.: Papierluftfilter in der Einsatzpraxis von Nutzfahrzeugen. MTZ, 58(1997), No 4.

[13] Traub M.: Mahle Symmetrix Hohe Filterleistung auf kleinem Bauraum, MTZ, 68, no. 2, 2007.

[14] WIX Filtron, Katalog filtrów: Gostyń 2010.

\section{Wnioski}

1. Współczynnik chłonności pyłu $\mathrm{k}_{\mathrm{m}}$ włókniny filtracyjnej wyznaczony z wykorzystaniem przedstawionej metodyki przyjmuje, dla prędkości filtracji z zakresu $\mathrm{v}_{\mathrm{F}}=0,08-0,27 \mathrm{~m} / \mathrm{s}$, odpowiednio wartości 343-290 g/m². Są to wartości większe niż dla papierów filtracyjnych wyznaczonych tą samą metodą $\left(\mathrm{k}_{\mathrm{m}}=190 \mathrm{~g} / \mathrm{m}^{2}\right)$, o czym decyduje trzykrotnie większa grubość włókniny.

2. Początkowy okres filtracji badanych włóknin charakteryzuje się mniejszą skutecznością i dokładnością filtracji niż papier filtracyjny oraz czterokrotnie dłuższym czasem osiągnięcia założonej (99,5 \%) skuteczności filtracji. Zjawisko to może wystąpić w czasie eksploatacji pojazdu (po wymianie wkładu filtracyjnego na nowy) i może być przyczyną przyspieszonego zużycia elementów silnika, a tym samym obniżenia jego trwałości.

3. Im mniejsza prędkość filtracji włóknin, tym rozmiary maksymalnych ziaren pyłu $\mathrm{d}_{\mathrm{zmax}}$ przyjmują mniejsze wartości i przy prędkości filtracji $v_{\mathrm{F}}=0,08 \mathrm{~m} / \mathrm{s}$ nie przekraczają $\mathrm{d}_{\mathrm{zmax}}=19 \mu \mathrm{m}$ w początkowym okresie filtracji i $\mathrm{d}_{\mathrm{zmax}}=$ $=3,8 \mu \mathrm{m}$ w okresie stabilnej pracy.

4. Pojawianie się za badanym wkładem filtracyjnym w końcowym etapie jego pracy ziaren pyłu o coraz większych rozmiarach wynika z tzw. zjawiska przebicia, które spowodowane jest dużymi prędkościami przepływu powietrza przez zapełnione pyłem medium filtracyjne. Nie jest to zjawisko lawinowe, lecz dotyczące pojedynczych ziaren w cyklach badawczych i nie występuje regularnie.

5. Badana filtracyjna struktura włókninowa dla zbliżonych warunków filtracji do papieru filtracyjnego charakteryzuje się nieznacznie mniejszą skutecznością i dokładnością filtracji, o czym świadczy skład granulometryczny pyłu w strumieniu powietrza za badanymi wkładami, ale dwukrotnie większą chłonnością pyłu.

6. Celowe byłoby zweryfikowanie kryteriów doboru włóknin na przegrody filtracyjne filtrów pojazdów mechanicznych i stosowanie wkładów filtracyjnych z włóknin dla prędkości filtracji nieprzekraczających $v_{F}=0,08 \mathrm{~m} / \mathrm{s}$.

Tadeusz Dziubak, DSc., DEng. - Professor at the Faculty of Mechanics Military University of Technology, Warsaw, Poland.

Dr hab. inż. Tadeusz Dziubak - profesor na Wydziale Mechanicznym Wojskowej Akademii Technicznej w Warszawie. e-mail: tdziubak@wat.edu.pl

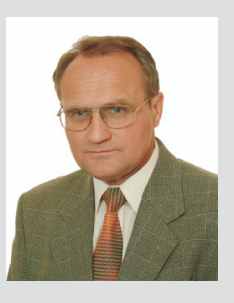

Sebastian Szwedkowicz, MEng. - PhD student in Faculty of Mechanical Engineering at Military University of Technology.

Mgr. inż. Sebastian Szwedkowicz - doktorant na Wydziale Mechanicznym Wojskowej Akademii Technicznej w Warszawie.

e-mail: sszwedkowicz@wat.edu.pl

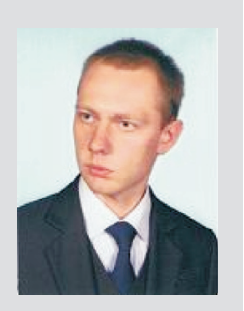

